\title{
Age of FS66 Kimberlite Beneath Murray Basin, South Australia: Laser Ablation ICP-MS Dating of Kimberlitic Zircon, Perovskite, and Rutile
}

\author{
Steven A. Cooper ${ }^{1,2}$, Elena A. Belousova ${ }^{1}$, W.L. Griffin ${ }^{1}$, \& Brian J. Morris ${ }^{3}$ \\ ${ }^{1}$ GEMOC ARC National Key Centre, Macquarie University, NSW, 2109, Australia \\ ${ }^{2}$ Orogenic Exploration Pty Ltd, Burwood, Vic, 3125, Australia \\ ${ }^{3}$ South Australia Geological Survey, PIRSA, Adelaide, SA, 5000, Australia
}

Grains of zircon, perovskite and rutile $(0.3-1.0 \mathrm{~mm}$ in size) have been recovered from a deeply buried kimberlite in South Australia. U-Pb ages of these grains have been determined using in situ LAMICPMS techniques at GEMOC, Macquarie University, Sydney. The kimberlitic pipe, designated FS66, is located 10.6 kilometres NNW of the town of Blanchetown along the Murray River, beneath 214 metres of Tertiary Murray Basin sediments. Another similar intrusion, designated FS3, is located nearby (Fig. 1). While described as breccia kimberlite (Lewis, 1985), the recovery of sample was limited to only very fine drill chips, with most minerals replaced by secondary carbonate and clays.

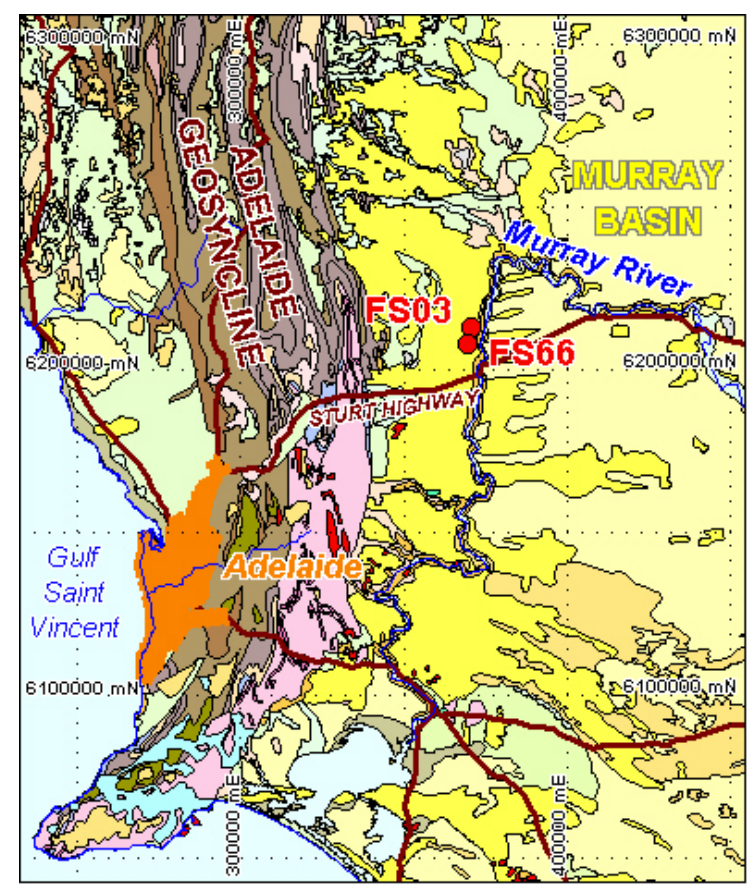

Figure 1. Location map of FS66 and FS03 kimberlitic pipes.

This is the first reported dating of zircon, perovskite and rutile from the same kimberlitic body. All analyses were performed using the laser ablation ICPMS technique. The validity of using a zircon standard for the perovskite analysis, and the accuracy of the methodology have been demonstrated by Batumike et al., (2007). Here we show that an analogous methodology can also be applied to rutile. All zircon and perovskite grains produced similar ${ }^{206} \mathrm{~Pb} /{ }^{238} \mathrm{U}$ ages within analytical uncertainty (Fig. 2). The weighted mean age of the FS66 zircon age is $179 \pm 2 \mathrm{Ma}(n=10$, Fig. 3). The perovskites contain significant initial $\mathrm{Pb}$, and the scatter in the data suggests that there is some heterogeneity in the isotopic composition of the initial $\mathrm{Pb}$. On the inverse-Concordia plot (Fig. 4) the mean lower intercept age is $181 \pm 16$ Ma $(n=74)$. We accept the more precise zircon age as the emplacement age of the kimberlite. A single kimberlitic Nb, Cr-rich rutile gave a weighted mean Concordia age of $197 \pm 6$ Ma (5 analyses) suggesting that it is a mantle-derived xenocryst (Fig. 5). The kimberlite has a strong positive-polarity magnetic anomaly, which is consistent with the normal (positive) paleomagnetic polarity for the period 180-179 Ma (Jones et al., 2001) matching the zircon age.

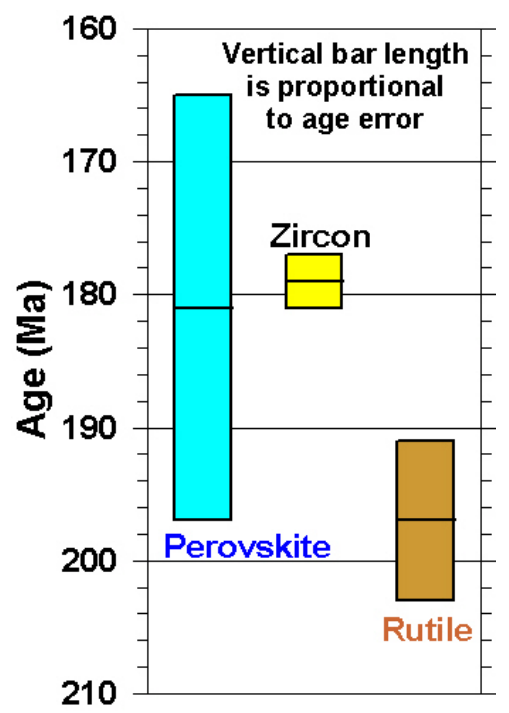

Figure 2. Ages of perovsike, zircon, and rutile from FS66 measured by LAM-ICPMS. 


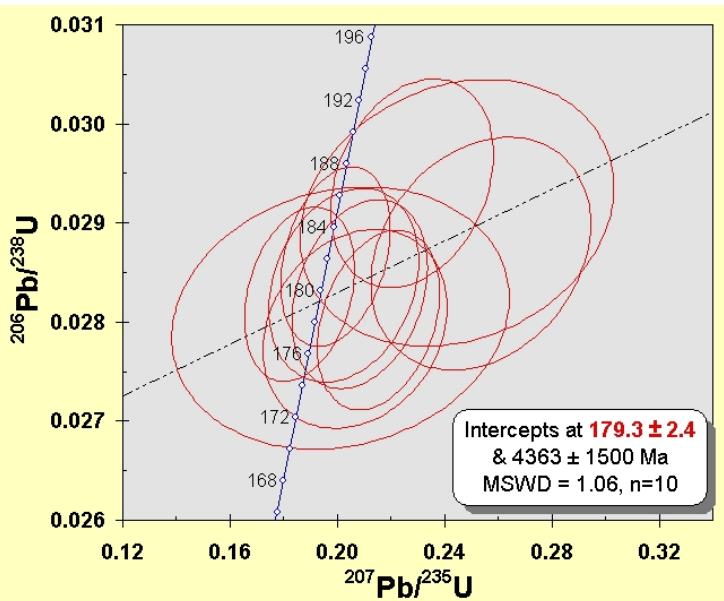

Figure 3. Concordia plot for FS66 zircons.
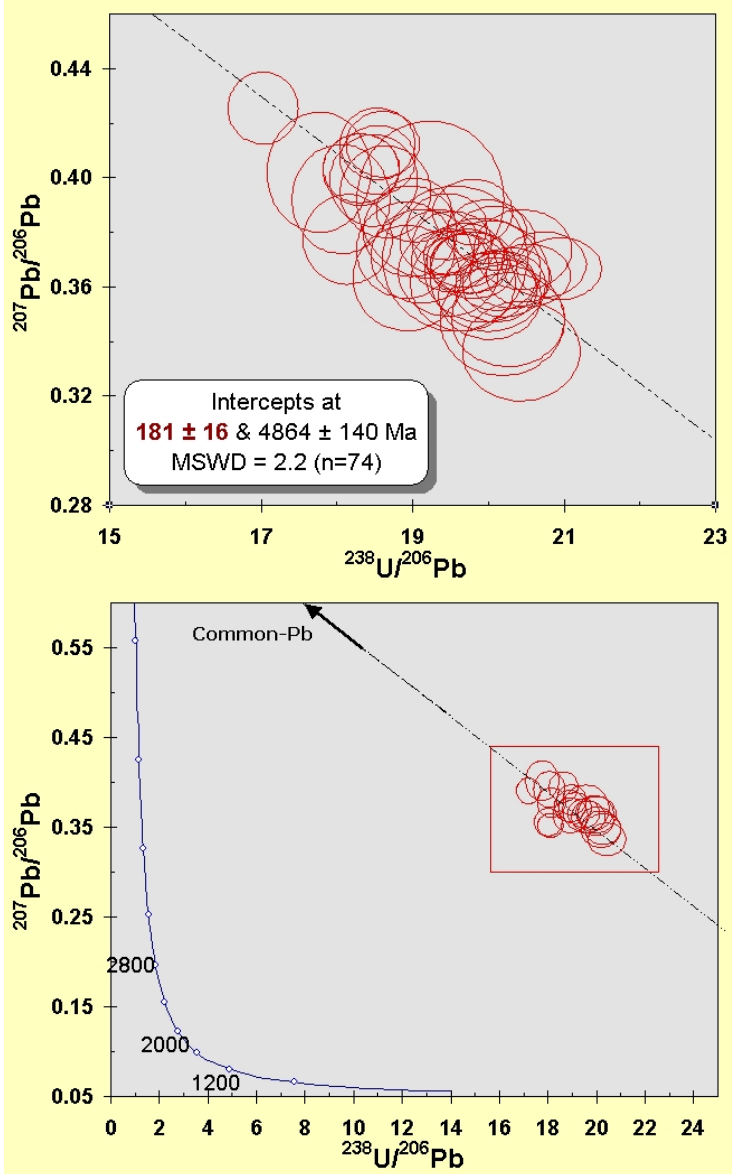

Figure 4. Inverse-Concordia plot for FS66 perovskites, all analyses $(n=80)$. The intercepts of the regression line diagram provide both an estimate of the ${ }^{207} \mathrm{~Pb} /{ }^{206} \mathrm{~Pb}$ of the inital-Pb cmponent (upper intercept) and the inferred crystallisation age (lower intercept).
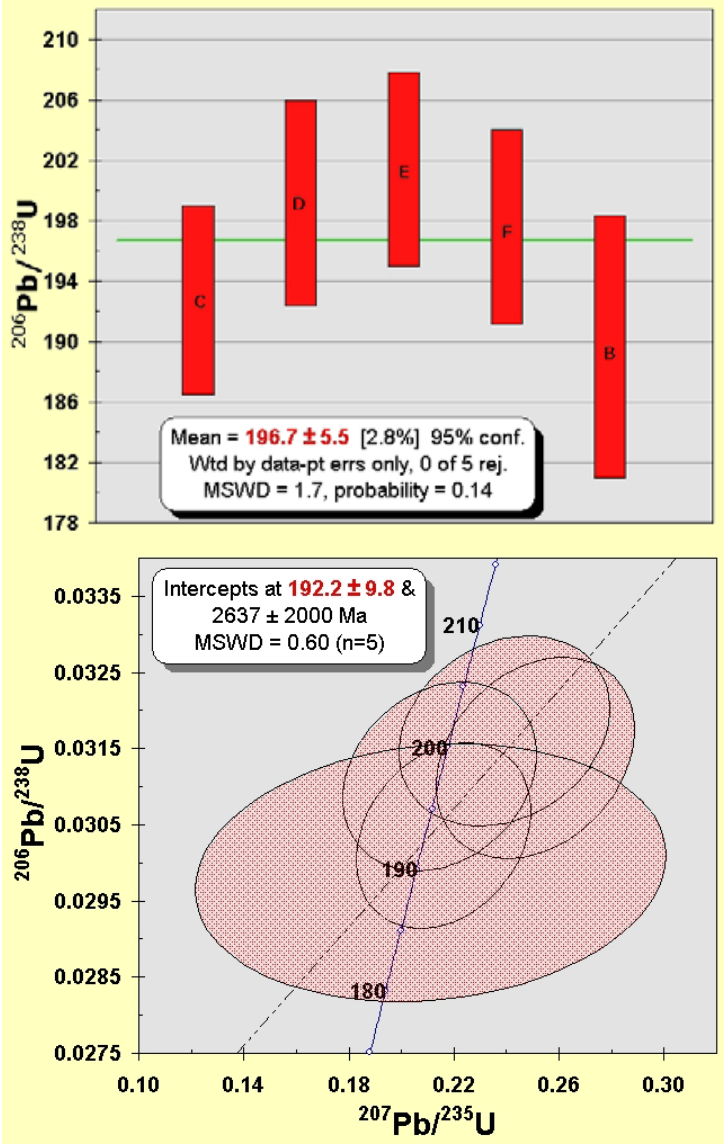

Figure 5. Weighted mean ${ }^{206} \mathrm{~Pb} /{ }^{238} \mathrm{U}$ age and Condordia plot for FS66 rutile.

Gaul (1993) determined a minimum temperature of $1100^{\circ} \mathrm{C}$ at the base of the lithosphere based on garnets from FS66 and FS3, and concluded that the lithospheric mantle volume sampled by the intrusions was not in the diamond stability field; this is consistent with the lack of microdiamonds in the drill samples (Lewis, 1985). Additional trace element work on recovered pyropes and chromites now improves this local lithospheric section. The maximum temperature of the rutile calculated from the $\mathrm{Zr}$ thermometer (Zack et al., 2004) is $1150^{\circ} \mathrm{C}$. This is slightly higher then the $900-1100^{\circ} \mathrm{C}$ and $20-30 \mathrm{~kb}$ range suggested for the stability of $\mathrm{Cr}-\mathrm{Nb}$-rutile formed by the reaction of peridotite with metasomatic fluids (Haggerty, 1983). The dated rutile grain has a fine lamellar intergrowth pattern of ilmenite (Fig. 6) and is distinguished from rutile in MARID xenoliths by high $\mathrm{Cr}$ values. The large phenocrysts of perovskite suggest an evolved kimberlitic intrusion. Perovskite REE patterns show strong LREE enrichment (Fig. 7). 


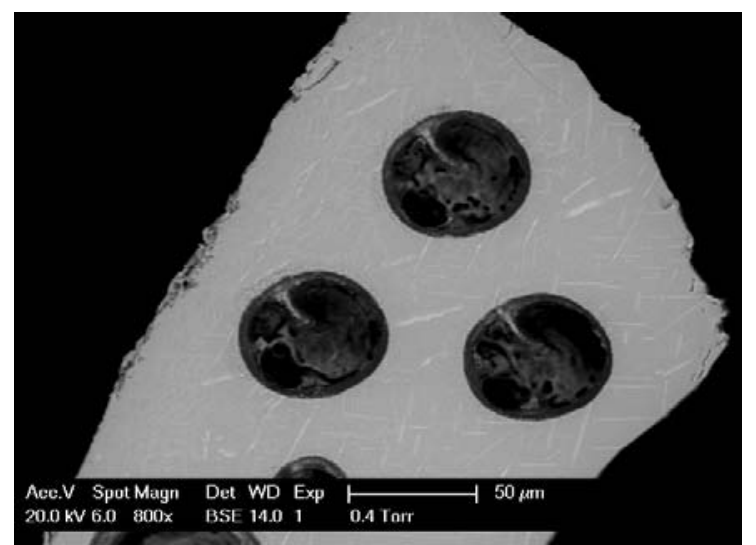

Figure 6. Backscatter image of rutile grain showing fine lamellar intergrowth and laser ablation spots used for dating,

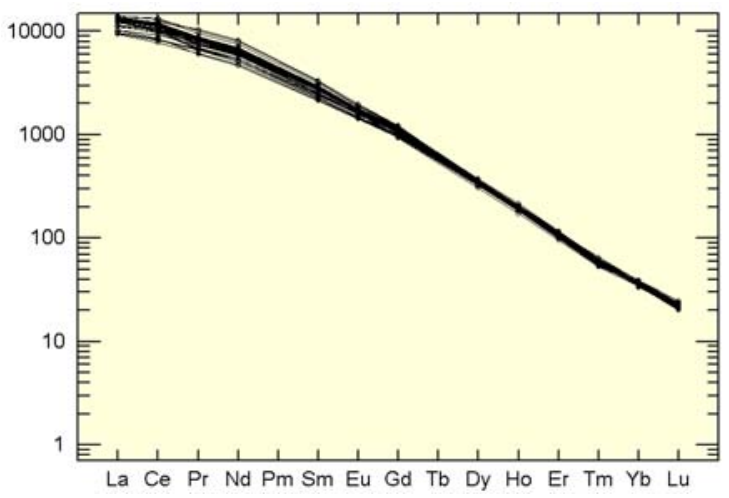

Figure 7. Chrondrite-normalised REE plot for FS66 perovskites.

Trace element studies (Yao, 1999; Belousova et al., 2002) of the chromites and zircons indicate that they are kimberlitic in nature, but no whole rock analyses are available to confirm the lithology. $\mathrm{Sr}$ and $\mathrm{Nd}$ isotopes in the perovskite, and Lu-Hf isotopes in the zircons and rutile constrain the composition and origin of the lithospheric mantle, and the sources of the kimberlitic intrusion. The initial ${ }^{87} \mathrm{Sr} /{ }^{86} \mathrm{Sr}$ ratios are $0.70417 \pm 0.00004(2 \mathrm{sd})$ and ${ }^{143} \mathrm{Nd} /{ }^{144} \mathrm{Nd}$ ratios are $0.51274 \pm 0.00007$ (2sd) for perovskite. The isotopic data for FS66 perovskite plot in the depleted quadrant on a Nd-Sr isotope diagram, and are close to those of many Jurassic-Cretaceous kimberlites.

\section{References}

Batumike, J.M., Griffin, W.L., Belousova, E.A., Pearson, N.J., O’Reilly, S.Y., \& Shee, S.R., 2008. LAM-ICPMS $\mathrm{U}-\mathrm{Pb}$ dating of kimberlitic perovskite: Eocene-Oligocene kimberlites from the Kundelungu Plateau, D.R. Congo. Earth \& Planetary Science Letters 267, 609-619.

Belousova, E.A., Griffin, W.L., O’Reilly, S.Y., \& Fisher, N.I., 2002. Igneous zircon: trace element composition as an indicator of source rock type. Contributions to Mineralogy and Petrology 143, 602-622.

Gaul, O.F., 1999. Composition of the Lithospheric Mantle beneath Australia. Unpublished $\mathrm{PhD}$ thesis, Macquarie University, Sydney.

Haggerty, S.E., 1983. The mineral chemistry of new titanates from the Jagersfontein Kimberlite, South Africa: Implications for metasomatism in the upper mantle. Geochimica et Cosmochimica 47, 1833-1854.

Jones, D.L., Duncan, R.A., Briden, J.C., Randall, D.E., \& MacNiocaill, C., 2001. Age of the Batoka Basalts, northern Zimbabwe, and the duration of Karoo Large Igneous Province magmatism. Geochemistry Geophysics Geosystems, 2. Paper No.2000GC000110.

Lewis, P., 1985. Final Report on the Murray Basin Tenements, South Australia for the period Ending 6 December 1984, Bungunnia EL1033, Kakoonie EL1034, Redcliffe EL1037, Waikerie EL1052 \& Narrung EL1053. Unpublished report by CRAE. PRISA Open-file Envelope 3957

Yao, S., 1999. Chemical Composition of Chromites from Ultramafic Rocks: Application to Mineral Exploration and Petrogenesis. Unpublished $\mathrm{PhD}$ thesis, Macquarie University, Sydney.

Zack, T., Moraes, R., \& Kronz, A., 2004. Temperature dependence of $\mathrm{Zr}$ in Rutile: empirical calibration of a Rutile Thermometer. Contributions to Mineralogy and Petrology, 148. 471-488.

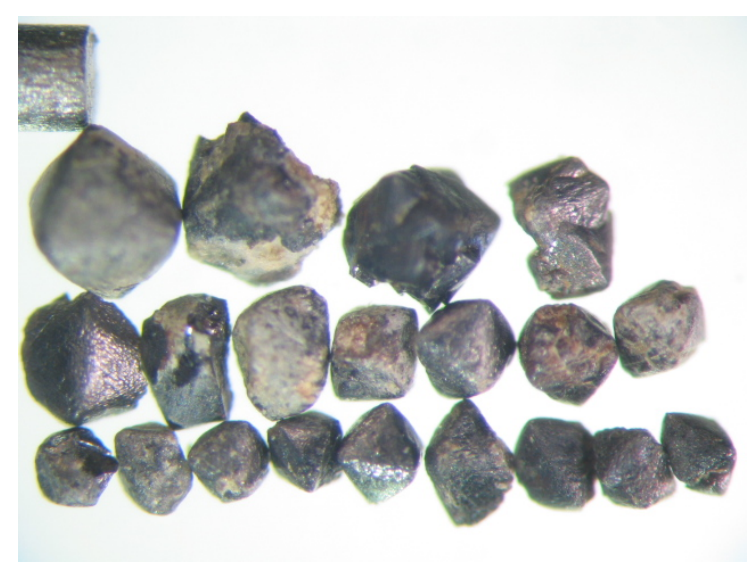

Figure 8. Perovskite from FS66 drillhole, scale (top left) is $0.5 \mathrm{~mm}$ wide. 